\title{
Analisis Respons dan Kinerja Struktur Bangunan Gedung Menggunakan Pushover Analysis
}

\author{
Analysis of Response and performance of Building Structures Using Pushover Analysis
}

\author{
Arie Putra Usman ${ }^{1}$, Rosidawani ${ }^{1 *}$, Sri Palta Mutmainna ${ }^{1}$ \\ ${ }^{1}$ Teknik Sipil, Universitas Sriwijaya, Jl. Raya Palembang-Prabumulih KM 32, Palembang, Indonesia
}

* Penulis korespondensi : rosidawani@ft.unsri.ac.id

Tel.: +62-8127889319; fax.:-

Diterima: 28 Agustus 2021; Direvisi: 31 Oktober 2021; Disetujui: 31 Oktober 2021

DOI: 10.25299/saintis2021.vol21(02).7585

\begin{abstract}
Abstrak
Indonesia merupakan negara dengan resiko gempa tinggi, hal ini diakibatkan oleh pertemuan lempeng-lempeng tektonik utama dan lempeng kecil lainnya yang mengelilingi Indonesia. Setiap wilayah Indonesia memiliki tingkat resiko gempa yang berbeda-beda, mulai dari resiko gempa rendah hingga resiko gempa tinggi. Tujuan dari penelitian ini adalah mengetahui perbandingan respons dan kinerja struktur suatu bangunan gedung di beberapa wilayah yang mewakili tingkat resiko gempa rendah hingga tinggi. Adapun wilayahwilayah yang ditinjau dalam penelitian ini yaitu wilayah Pontianak, Palembang, Jakarta, Bandar Lampung, dan Palu. Analisis dilakukan pada bangunan beton bertulang empat lantai dengan dinding geser menggunakan bantuan program SAP 2000 guna mendapatkan respons dan kinerja struktur. Hasil respons struktur dari penelitian menunjukkan nilai simpangan lateral lantai dari yang terbesar hingga terkecil yaitu dimulai dari wilayah Palu, Bandar Lampung, Jakarta, Palembang, dan Pontianak. Wilayah Palu memiliki nilai simpangan lateral lantai yang terbesar yaitu 23,745 $\mathrm{mm}$ dan 23,690 $\mathrm{mm}$ untuk arah X dan Y sedangkan wilayah Pontianak memiliki nilai simpangan lateral lantai terkecil dengan besar simpangan lateral 7,571 mm dan 7,439 mm untuk arah X dan Y. Berdasarkan analisis pushover didapatkan level kinerja struktur memiliki level kinerja B untuk Wilayah Palu dan IO untuk wilayah lainnya.
\end{abstract}

Kata Kunci: Gempa, Level Kinerja, Respons Struktur, Pushover Analysis

\begin{abstract}
Indonesia is a country with a high risk of earthquake due to the meeting of the main tectonic plates and other small plates that surround Indonesia. Each area in this country has a different level of earthquake risk, ranging from low to high earthquake risk. This study aims to compare the response and structural performance of buildings in some areas with low to high earthquake risk levels. The areas covered Pontianak, Palembang, Jakarta, Bandar Lampung, and Palu. The analysis was carried out on a four-story reinforced concrete with shear walls using the SAP 2000 program to obtain the response and performance of the building structure. The results of the structural response showed the value of the floor lateral deviation from the largest to the smallest, starting from Palu, Bandar Lampung, Jakarta, Palembang, and Pontianak. Pulu has the largest floor lateral deviation values of $23.745 \mathrm{~mm}$ and $23.690 \mathrm{~mm}$ for the X and $Y$ directions, while Pontianak has the smallest floor lateral deviation values of $7.571 \mathrm{~mm}$ and $7.439 \mathrm{~mm}$ for the $X$ and $Y$ directions. Based on the pushover analysis, the structure has a performance level of $B$ for Palu areas and IO for other areas.
\end{abstract}

Keywords: Earthquake, Performance Level, Structure Response, Pushover Analysis

\section{PENDAHULUAN}

Wilayah Indonesia memiliki potensi terjadinya gempa yang bervariasi, mulai dari potensi gempa rendah sampai dengan tinggi. Dampak dari gempa itu sendiri mengakibatkan adanya kerusakan pada gedung, jembatan, jalan, rumah, dan lain-lain. Perencanaan suatu struktur bangunan tersebut perlu dilakukan sebaik mungkin agar dapat meminimalisir dampak akibat terjadinya gempa.

Salah satu faktor yang memengaruhi struktur dalam menerima beban yaitu konfigurasi struktur, dimana bangunan yang berkonfigurasi teratur lebih baik dalam menahan gaya gempa sehingga kerusakan struktur dapat dihindari [1][2]. Selain itu, besarnya gaya gempa juga memengaruhi respons struktur yang terjadi diakibatkan karena gaya gempa akan diterima oleh dasar bangunan [3][4]. Dari gaya gempa yang diberikan pada struktur, dapat ditentukan respons dan kinerja struktur pada setiap wilayah Indonesia yang mewakili wilayah dengan resiko gempa rendah sampai dengan tinggi. Peraturan yang digunakan dalam perhitungan gempa yaitu SNI 1726-2019 [5], dimana dalam peraturan tersebut terdapat nilai koefisien gempa yang digunakan dalam perencanaan struktur. Penelitian ini mengambil wilayah Pontianak, Palembang, Jakarta, Bandar Lampung, dan Palu sebagai beberapa contoh wilayah yang ada di Indonesia yang mewakili wilayah dengan gempa rendah hingga tinggi. Tujuan dari penelitian ini yaitu untuk menganalisis respons dan kinerja struktur pada bangunan beton 
bertulang di beberapa wilayah berbeda berdasarkan peraturan SNI 1726:2019 dan metode FEMA 440.

\section{METODOLOGI}

Perhitungan respons dan kinerja struktur dilakukan dibeberapa wilayah di Indonesia dengan data-data mengenai bangunan beton bertulang yang ditinjau yaitu:
Fungsi gedung
Tinggi lantai 1
$=$ Rumah Sakit 4 Lantai
Tinggi lantai 2-atap
$=4,5 \mathrm{~m}$
Panjang
$=4,2 \mathrm{~m}$
Lebar
$=36 \mathrm{~m}$
Mutu beton
$=43,2 \mathrm{~m}$
$=35 \mathrm{MPa}$
Mutu baja
$=400 \mathrm{MPa}$ Gambar 1.

Tahapan dalam penelitian dapat dilihat pada

\section{Studi Pustaka}

Penelitian ini dimulai dengan melakukan pengumpulan infomasi yang berhubungan dengan topik penelitian melalui studi literatur. Peraturanperaturan yang digunakan untuk mendasari perhitungan pada penelitian ini dapat dilihat pada Tabel 1.

Tabel 1. Peraturan-Peraturan yang Digunakan

\begin{tabular}{ll}
\hline Perhitungan & Peraturan \\
\hline Pembebanan & SNI 1727:2020 \\
Beban Gempa & SNI 1726:2019 \\
Beton Bertulang & SNI 1727:2019 \\
Kinerja Struktur & FEMA 440 \\
\hline
\end{tabular}

\section{Preliminary Design}

Preliminary design merupakan perencanaan dimensi elemen struktur yang meliputi balok, kolom, pelat lantai, dan dinding geser yang mengacu pada SNI 2847:2019. Hasil perencanaan yang didapat kemudian dimodelkan dengan program SAP 2000 sesuai pada data-data yang sudah didapat dengan langkah-langkah sebagai berikut:

1. Define grid data, dilakukan untuk mempermudah dalam mengaplikasikan elemen struktur yang akan digambarkan.

2. Define material, dilakukan guna memasukkan data material agar sesuai dengan spesifikasi material yang telah ditentukan.

3. Define elemen struktur, dilakukan guna menggambarkan elemen struktur berupa balok, kolom, pelat lantai, dan dinding geser mulai dari dimensi, tulangan, dan juga mutu material yang digunakan.

Struktur yang telah dimodelkan dengan program SAP 2000 dapat dilihat pada Gambar 2.

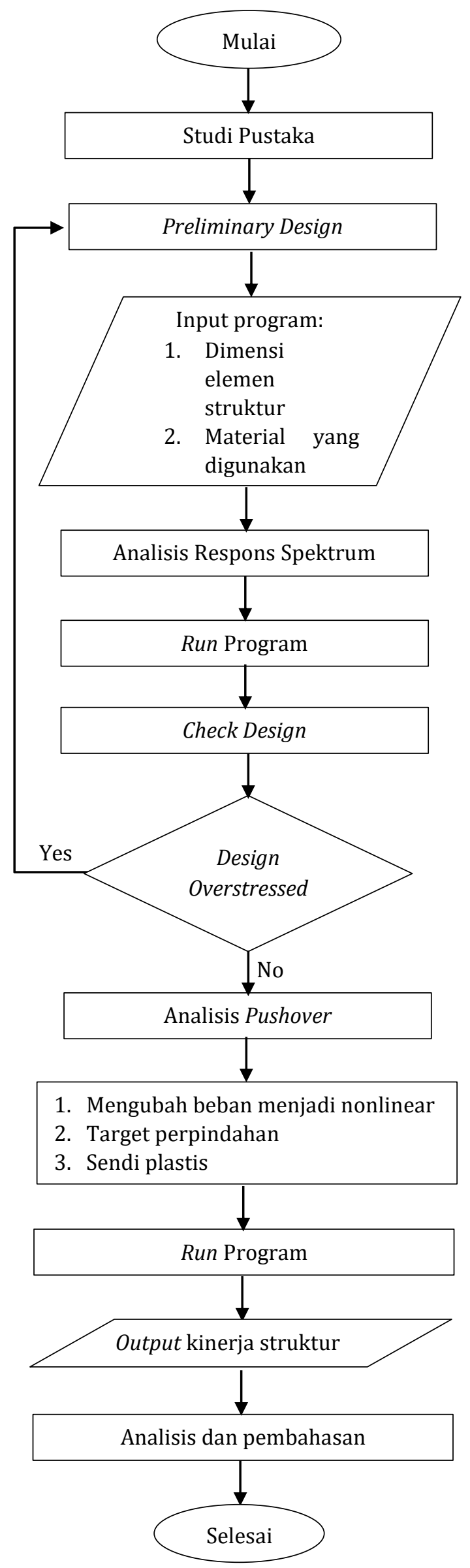

Gambar 1. Diagram Alir Penelitian 


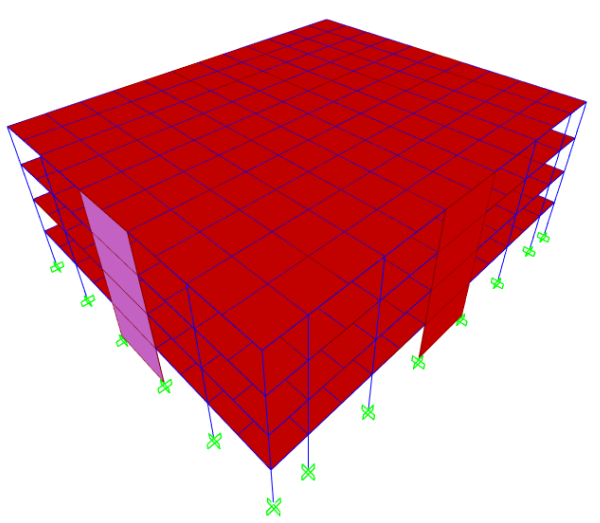

Gambar 2. Model Struktur yang Digunakan

\section{Input Data Struktur}

Tahapan input data struktur dilakukan setelah pemodelan, dimana pada tahapan ini dilakukan input data-data struktur yang diperlukan antara lain data dimensi elemen struktur, data material elemen struktur dan data beban yang digunakan. Beban-beban yang telah diinput akan diterima oleh struktur bangunan gedung sehingga kemudian dihasilkan respons dan kinerja struktur dari gedung tersebut. Pembebanan yang dilakukan meliputi beban mati, beban hidup, dan beban gempa. Beban mati ditentukan berdasarkan PPPURG 1987 dan SNI 1727:2020 [6], beban hidup dan gempa ditentukan berdasarkan SNI 1727:2020 dan SNI 1726:2019. Beban mati terdiri dari berat seluruh bahan konstruksi bangunan gedung yang terpasang [7]. Untuk beban hidup merupakan beban yang diakibatkan oleh pengguna dan penghuni bangunan gedung [6] sedangkan beban gempa merupakan beban yang perlu dianalisis dengan baik karena besaran dan waktu terjadinya gempa cukup sulit untuk diprediksi [8]. Dalam menghitung beban gempa, dibutuhkan koefisien kegempaan pada setiap wilayah yang diperoleh dari website PU Cipta Karya. Koefisien kegempaan ini diperlukan untuk menghitung parameterparameter kegempaan yang digunakan untuk menggambarkan kurva respons spektrum. Koefisien kegempaan pada setiap wilayah yang ditinjau disajikan dalam Tabel 2.

Tabel 2. Koefisien Kegempaan

\begin{tabular}{cclcc}
\hline No. & Wilayah & Kelas Situs & $\mathbf{S}_{\mathbf{s}}$ & \multicolumn{1}{c}{$\mathbf{S}_{\mathbf{1}}$} \\
\hline 1. & Pontianak & $\begin{array}{l}\text { Tanah Lunak } \\
\text { (SE) }\end{array}$ & 0,1756 & 0,0510 \\
2. & Palembang & $\begin{array}{l}\text { Tanah Lunak } \\
\text { (SE) }\end{array}$ & 0,2909 & 0,2485 \\
3. & Jakarta & $\begin{array}{l}\text { Tanah Lunak } \\
\text { (SE) }\end{array}$ & 0,7806 & 0,3823 \\
4. & B.Lampung & $\begin{array}{l}\text { Tanah Lunak } \\
\text { (SE) }\end{array}$ & 0,8739 & 0,4306 \\
5. & Palu & $\begin{array}{l}\text { Tanah Lunak } \\
\text { (SE) }\end{array}$ & 1,5000 & 0,6000 \\
\hline
\end{tabular}

Selanjutnya, beban-beban yang digunakan tersebut dikombinasikan dari setiap kemungkinan yang terjadi berdasarkan peraturan SNI 1726:2019. Berikut kombinasi pembebanan yang digunakan:

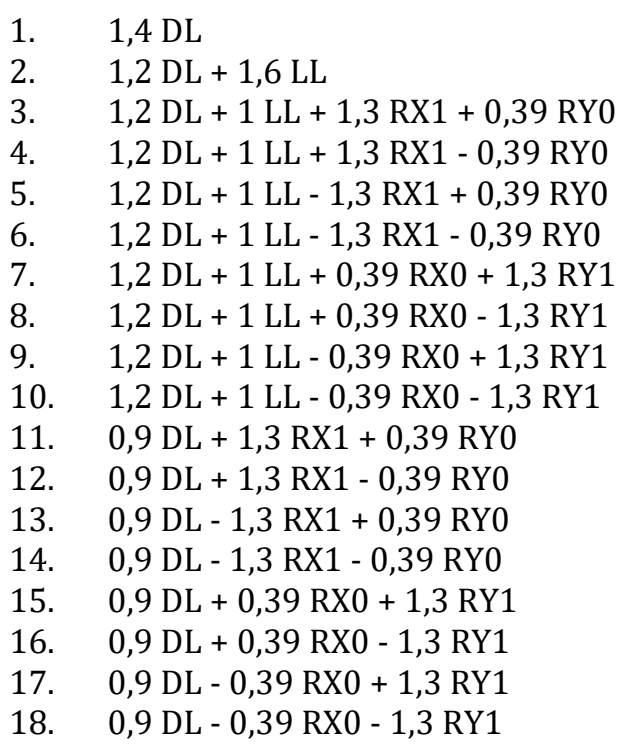

\section{Analisis Linear dan Non-linear}

Tahapan analisis dilakukan setelah pemodelan dan pembebanan pada bangunan yang ditinjau pada setiap wilayahnya. Terdapat dua tahap analisis yang dilakukan, yang pertama yaitu analisis linear (analisis respons spektrum) dan yang kedua yaitu analisis non-linear (analisis pushover).

Pada analisis linear dilakukan perhitungan gaya geser dasar dan perhitungan simpangan antar lantai untuk mengetahui aman atau tidaknya struktur yang digunakan. Perhitungan gaya geser dasar mengacu pada peraturan SNI 1726:2019, dimana terdapat koefisien-koefisien yang ditentukan dalam menghitung gaya geser dasar. Adapun langkah-langkah dalam menghitung gaya geser dasar seismik yaitu sebagai berikut:

1. Menentukan kategori resiko gedung yang dapat dilihat pada tabel 3 SNI 1726:2019.

2. Menentukan kategori desain seismik pada masing-masing wilayah berdasarkan tabel 8 dan 9 SNI 1726:2019.

3. Menentukan faktor reduksi berdasarkan tabel 12 SNI 1726:2019 yang hasilnya yaitu: $\mathrm{R}=8 ; \Omega_{0}=3 ; \mathrm{C}_{\mathrm{d}}=5,5$.

4. Menentukan periode fundamental, dimana persamaannya sebagai berikut:

$\mathrm{T}_{\mathrm{a}} \leq \mathrm{T}_{\mathrm{x}} \leq \mathrm{C}_{\mathrm{u}} \mathrm{T}_{\mathrm{a}}$
$\mathrm{C}_{\mathrm{t}} \times \mathrm{h}_{\mathrm{n}} \mathrm{x} \leq \mathrm{T}_{\mathrm{x}} \leq \mathrm{C}_{\mathrm{u}} \mathrm{T}_{\mathrm{a}}$

Nilai $\mathrm{T}_{\mathrm{x}}$ harus lebih kecil dari $\mathrm{C}_{\mathrm{u}} \mathrm{T}_{\mathrm{a}}$, apabila $\mathrm{T}_{\mathrm{x}}$ lebih besar dari $\mathrm{C}_{\mathrm{u}} \mathrm{T}_{\mathrm{a}}$ maka nilai $\mathrm{T}$ yang digunakan sebesar $\mathrm{C}_{\mathrm{u}} \mathrm{T}_{\mathrm{a}}$.

5. Menentukan koefisien desain seismik $\left(\mathrm{C}_{\mathrm{s}}\right)$ berdasarkan pasal 7.8.1.1. SNI 1726:2019.

$$
\begin{aligned}
& \mathrm{C}_{\mathrm{s} \min } \leq \mathrm{C}_{\mathrm{s}} \leq \mathrm{C}_{\mathrm{s} \text { maks }} \\
& 044 \mathrm{~S}_{\mathrm{DS}} \times \mathrm{I}_{\mathrm{e}} \leq \mathrm{C}_{\mathrm{s}} \leq \frac{S_{D 1}}{T\left(\frac{R}{I_{e}}\right)}
\end{aligned}
$$

Nilai $\mathrm{C}_{\mathrm{s}}$ harus lebih kecil dari $\mathrm{C}_{\mathrm{s}}$ maks, apabila $\mathrm{C}_{\mathrm{s}}$ lebih besar dari $\mathrm{C}_{\mathrm{s} \text { maks }}$ maka nilai $\mathrm{C}_{\mathrm{s}}$ yang digunakan sebesar $\mathrm{C}_{\text {s maks }}$.

6. Menentukan gaya geser dasar seismik dengan persamaan sebagai berikut:

$$
\mathrm{V} \quad=\mathrm{C}_{\mathrm{s}} \times \mathrm{W}
$$




$$
\begin{aligned}
\mathrm{W}= & \text { Berat Sendiri Struktur }+ \text { Beban } \\
& \text { Mati }+30 \% \text { Beban Hidup }
\end{aligned}
$$

Analisis linear yaitu perhitungan simpangan antar lantai. Dalam menghitung nilai simpangan antar lantai, dibutuhkan nilai simpangan lateral yang diakibatkan oleh beban gempa yang diberikan. Nilai simpangan lateral dapat ditampilkan melalui program SAP 2000 yang selanjutnya nilai tersebut dimasukkan dalam perhitungan simpangan antar lantai. Simpangan antar lantai dihitung berdasarkan pasal 7.8.6. SNI 1726:2019. Simpangan antar lantai itu sendiri merupakan simpangan yang terjadi pada pusat masa yang berada di atas atau di bawah lantai yang ditinjau. Berikut langkah-langkah perhitungan simpangan antar lantai:

1. Menentukan nilai $\mathrm{C}_{\mathrm{d}}, \mathrm{I}_{\mathrm{e}}$, dan $\mathrm{h} \mathrm{s}_{\mathrm{x}}$

2. Menampilkan simpangan lateral $\left(\delta_{\mathrm{e}}\right)$

3. Menghitung simpangan yang diperbesar dengan rumus sebagai berikut:

$$
\delta_{\mathrm{I}} \quad=\frac{C_{d} \times \delta_{e}}{I_{e}}
$$

4. Menentukan simpangan antar lantai izin, dimana perhitungan yang digunakan berdasarkan tabel 20 SNI 1726:2019 yang ditentukan oleh jenis struktur dan kategori resiko. Dalam penelitian ini, bangunan yang digunakan termasuk dalam kategori resiko IV dan didapat perhitungan sebagai berikut:

$\Delta_{\text {izin }} \quad=0,015 \mathrm{~h}_{\mathrm{Sx}}$

5. Menghitung simpangan antar lantai, dimana nilainya tidak boleh melebihi dari simpangan antar lantai izin.

Untuk lantai dasar:

$\Delta_{1}=\delta_{1} \leq \Delta_{\text {izin }}$

Untuk lantai 2 dan seterusnya:

$\Delta_{2}=\left(\delta_{\mathrm{e} 2}-\delta_{\mathrm{e} 1}\right) \mathrm{C}_{\mathrm{d}} / \mathrm{I}_{\mathrm{E}} \leq \Delta_{\mathrm{izin}}$

6. Apabila simpangan yang simpangan antar lantai $\left(\Delta_{\mathrm{i}}\right)$ lebih kecil dari simpangan antar lantai izin $\left(\Delta_{\text {izin }}\right)$, maka struktur dapat dikategorikan aman. Namun apabila simpangan antar lantai $\left(\Delta_{\mathrm{i}}\right)$ lebih besar dari simpangan antar lantai izin $\left(\Delta_{\text {izin }}\right)$, maka struktur dapat dikategorikan tidak aman karena keadaan struktur mengalami keruntuhan.

Bangunan yang sudah dinyatakan aman, berdasarkan analisis linear kemudian akan dianalisis secara non-linear (Pushover Analysis). Analisis ini menjadi penting karena pada saat gempa besar terjadi, beberapa elemen struktur seperti balok dan kolom akan mengalami pelelehan sendi plastis [9].

Analisis pushover dilakukan dengan cara memberikan beban statis secara bertahap hingga struktur tersebut mengalami keruntuhan. Penempatan beban pada analisis ini dilakukan secara horizontal yang merupakan kombinasi dari beban gempa, beban hidup dan beban mati [10].

Dalam penelitian ini, perhitungan analisis pushover dilakukan berdasarkan metode FEMA 440
[11]. Metode FEMA 440 merupakan pengembangan dari FEMA 356 (metode koefisien perpindahan) [12]. Prosedur perhitungan FEMA 440 dimulai dengan menentukan waktu getar efektif (Te) [12]. Untuk mengetahui nilai waktu getar alami suatu struktur, diperlukan nilai waktu getar efektif dari kurva pushover [13]. Penyelesaian ini dilakukan dengan cara modifikasi respon elastis sistem single degree of freedom ekuivalen dengan faktor-faktor koefisien $\mathrm{C}_{0}, \mathrm{C}_{1}, \mathrm{C}_{2}$, dan $\mathrm{C}_{3}$ sehingga didapatkan nilai terbesar perpindahan global baik dalam kondisi elastis maupun inelastis yang disebut dengan target perpindahan $\left(\delta_{\mathrm{T}}\right)$ [12]. Adapun rumus yang digunakan dalam menentukan target perpindahan $\left(\delta_{\mathrm{T}}\right)$ yaitu sebagai berikut:

$\delta_{\mathrm{T}}=\mathrm{C}_{0} \mathrm{C}_{1} \mathrm{C}_{2} \mathrm{C}_{3} \mathrm{~S}_{\mathrm{a}} \frac{T_{e}^{2}}{4 \pi^{2}} \mathrm{~g}$

\section{HASIL DAN DISKUSI}

\section{Hasil Perhitungan Volume Elemen Struktur}

Dari hasil perencanaan dimensi elemen struktur balok, kolom, pelat lantai, dan dinding geser, didapat dimensi elemen struktur seperti disajikan dalam Tabel 3.

Tabel 3. Dimensi Elemen Struktur

\begin{tabular}{lcccccc}
\hline \multirow{2}{*}{ Wilayah } & \multicolumn{2}{c}{ B1 (mm) } & \multicolumn{2}{c}{ B2 (mm) } & \multicolumn{2}{c}{ BA (mm) } \\
\cline { 2 - 7 } & h & b & h & b & h & b \\
\hline Pontianak & 500 & 300 & 500 & 250 & 400 & 200 \\
Palembang & 600 & 300 & 500 & 250 & 400 & 200 \\
Jakarta & 600 & 400 & 500 & 250 & 400 & 200 \\
Bandar & 700 & 350 & 500 & 300 & 400 & 200 \\
Lampung & & & & & & \\
Palu & 700 & 400 & 500 & 300 & 400 & 200 \\
\hline
\end{tabular}

Tabel 3. Dimensi Elemen Struktur (Lanjutan)

\begin{tabular}{lcccc}
\hline \multirow{2}{*}{ Wilayah } & \multicolumn{2}{c}{ K (mm) } & SW & P \\
\cline { 2 - 3 } & $\mathbf{h}$ & $\mathbf{b}$ & $\mathbf{( m m )}$ & $\mathbf{( m m )}$ \\
\hline Pontianak & 500 & 500 & 300 & 120 \\
Palembang & 500 & 500 & 300 & 120 \\
Jakarta & 500 & 500 & 300 & 120 \\
$\begin{array}{l}\text { Bandar } \\
\text { Lampung }\end{array}$ & 500 & 500 & 300 & 120 \\
Palu & 500 & 500 & 300 & 120 \\
\hline
\end{tabular}

Dari hasil perencanaan dimensi elemen struktur yang didapat, maka dapat dihitung volume elemen struktur pada masing-masing wilayah. Nilai-nilai volume elemen truktur tersebut dapat dilihat pada Tabel 4, dimana wilayah Palu memiliki nilai terkecil dengan persen perbedaan sebesar $11,30 \%$

Tabel 4. Volume Elemen Struktur

\begin{tabular}{lcc}
\hline \multirow{2}{*}{ Wilayah } & \multicolumn{2}{c}{ Volume Elemen Struktur $\left(\mathbf{m}^{3}\right)$} \\
\cline { 2 - 3 } & Total & $\begin{array}{r}\text { \% Perbedaan } \\
\text { Total Volume }\end{array}$ \\
\hline Pontianak & 1476,22 & 0 \\
Palembang & 1509,05 & 2,22 \\
Jakarta & 1574,71 & 6,67 \\
Bandar Lampung & 1604,66 & 8,70 \\
Palu & 1642,97 & 11,30 \\
\hline
\end{tabular}




\section{Hasil Perhitungan Pembebanan}

Dalam pemberian pembebanan pada bangunan beton bertulang, diberikan nilai beban mati dan beban hidup yang sama pada setiap wilayahnya. Sedangkan, untuk beban gempa diberikan nilai yang berbeda sesuai dengan perhitungan beban gempa pada masing-masing wilayah. Dalam hal ini beban gempa dianalisis menggunakan metode respons spektrum [14]. Berikut disajikan dalam Tabel 5 mengenai perhitungan desain respons spektrum pada wilayah yang ditinjau.

Tabel 5. Parameter Kegempaan

\begin{tabular}{lcccc}
\hline \multicolumn{1}{c}{ Wilayah } & SDs $\left._{\mathbf{D}} \mathbf{g}\right)$ & $\mathbf{S}_{\mathbf{D} \mathbf{1}} \mathbf{( g )}$ & $\mathbf{T}_{\mathbf{0}}(\mathbf{s})$ & $\mathbf{T}_{\mathbf{s}}(\mathbf{s})$ \\
\hline Pontianak & 0,187 & 0,082 & 0,09 & 0,44 \\
Palembang & 0,443 & 0,507 & 0,23 & 1,14 \\
Jakarta & 0,664 & 0,630 & 0,19 & 0,95 \\
Bandar & 0,699 & 0,671 & 0,19 & 0,96 \\
Lampung & 0,8 & 0,68 & 0,17 & 0,85 \\
Palu & 0,
\end{tabular}

Dari parameter-parameter $\mathrm{S}_{\mathrm{DS}}, \mathrm{S}_{\mathrm{D} 1}, \mathrm{~T}_{0}$, dan $\mathrm{T}_{\mathrm{s}}$, dapat digambarkan kurva desain respons spektrum disetiap wilayah yang ditinjau yang disajikan dalam Gambar 3.

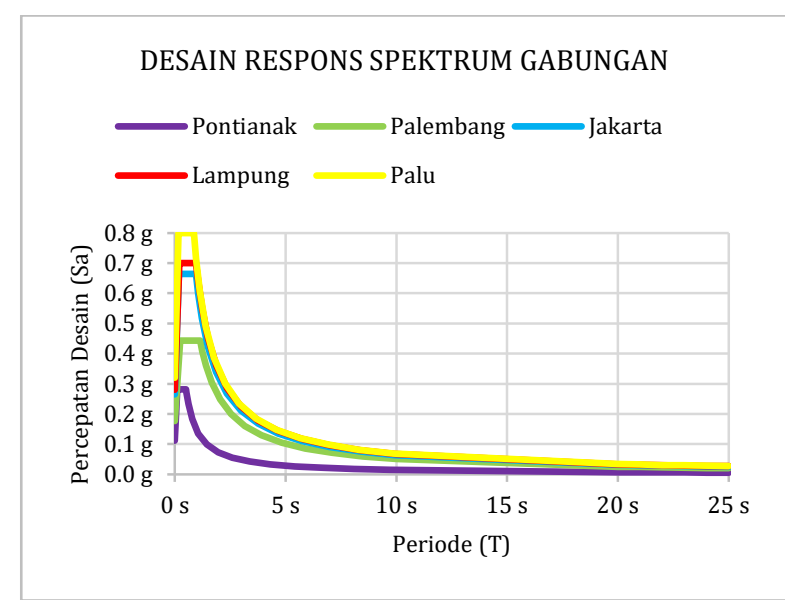

Gambar 3. Desain Respons Spektrum Gabungan

\section{Hasil Perhitungan Gaya Geser Dasar Seismik}

Untuk mendapatkan hasil perhitungan gaya geser dasar seismik, dibutuhkan nilai periode fundamental struktur, koefisien desain seismik, dan berat struktur dalam perhitungannya. Berikut disajikan dalam Tabel 6 dan 7 berupa hasil perhitungan periode fundamental struktur, keofisien desain seismik, berat struktur, dan gaya geser dasar seismik.

Tabel 6. Periode Fundamental Struktur

\begin{tabular}{lcccc}
\hline \multicolumn{1}{c}{ Wilayah } & SD1 $_{\text {Dianak }}$ & $\mathbf{C}_{\mathbf{u}}$ & $\mathbf{C}_{\mathbf{t}}$ & $\mathbf{x}$ \\
\hline Pontian & 0,143 & 1,6 & 0,0466 & 0,9 \\
Palembang & 0,507 & 1,4 & 0,0466 & 0,9 \\
Jakarta & 0,630 & 1,4 & 0,0466 & 0,9 \\
Bandar & 0,671 & 1,4 & 0,0466 & 0,9 \\
Lampung & & & & \\
Palu & 0,680 & 1,4 & 0,0466 & 0,9 \\
\hline
\end{tabular}

Tabel 6. Periode Fundamental Struktur

\begin{tabular}{lccc}
\multicolumn{4}{c}{ (Lanjutan) } \\
\hline \multicolumn{1}{c}{ Wilayah } & $\mathrm{T}_{\mathrm{a}}(\mathrm{s})$ & $\mathrm{C}_{\mathrm{u}} \mathrm{T}_{\mathrm{a}}$ & $\mathrm{T}_{\text {a pakai }}(\mathrm{s})$ \\
\hline Pontianak & 0,600 & 0,840 & 0,680 \\
\hline Palembang & 0,600 & 0,840 & 0,646 \\
\hline Jakarta & 0,600 & 0,840 & 0,636 \\
\hline Bandar Lampung & 0,600 & 0,840 & 0,617 \\
\hline Palu & 0,600 & 0,840 & 0,613 \\
\hline
\end{tabular}

Tabel 7. Koefisien Desain Seismik (Cs)

\begin{tabular}{lccll}
\hline \multicolumn{1}{c}{ Wilayah } & C $_{\text {s min }}$ & C $_{\boldsymbol{s}}$ & C $_{\text {s maks }}$ & C $_{\text {s pakai }}$ \\
\hline Pontianak & 0,019 & 0,053 & 0,039 & 0,039 \\
Palembang & 0,029 & 0,083 & 0,147 & 0,083 \\
Jakarta & 0,045 & 0,127 & 0,186 & 0,127 \\
Bandar Lampung & 0,050 & 0,142 & 0,204 & 0,142 \\
Palu & 0,056 & 0,150 & 0,208 & 0,150 \\
\hline
\end{tabular}

Tabel 8. Berat Total Struktur dan Gaya Geser Dasar Seismik

\begin{tabular}{lccc}
\hline \multicolumn{1}{c}{ Wilayah } & $\mathrm{C}_{\mathrm{s}}$ & $\mathrm{W}$ (ton) & V (ton) \\
\hline Pontianak & 0,038 & 4699,61 & 185,16 \\
Palembang & 0,083 & 4778,40 & 397,11 \\
Jakarta & 0,127 & 4935,99 & 626,11 \\
Bandar & 0,142 & 5007,88 & 711,16 \\
Lampung & 0,150 & 5099,81 & 764,97 \\
Palu &
\end{tabular}

Dari Tabel 8, dapat dilihat bahwa wilayah Palu memiliki nilai gaya geser dasar terbesar dan wilayah Pontianak memiliki gaya geser dasar terkecil. Hal ini disebabkan karena pada wilayah Palu memiliki gaya gempa yang lebih besar dibandingkan dengan wilayah lainnya, sehingga koefisien kegempaan yang didapat lebih besar dan dapat memengaruhi nilai perhitungan gaya geser dasar seismik.

\section{Hasil Perhitungan Simpangan Antar Lantai}

Simpangan antar lantai dihitung berdasarkan simpangan lateral lantai yang terjadi, dimana gaya geser dasar juga memengaruhi nilai simpangan antar lantai [15]. Simpangan pada lantai tersebut terjadi akibat adanya gaya pada tiap lantai bangunan [4]. Gaya geser dasar yang didistribusikan ke setiap lantainya akan menghasilkan gaya lateral yang semakin besar sesuai dengan ketinggian struktur yang digunakan. Berikut disajikan dalam Tabel 9 dan 10 gaya lateral lantai yang diambil dari hasil program SAP 2000.

Tabel 9. Simpangan Lateral Lantai Arah X

\begin{tabular}{cccccc}
\hline & \multirow{2}{*}{$\mathbf{H}$} & \multicolumn{2}{c}{ Pontianak } & \multicolumn{2}{c}{ Palembang } \\
\cline { 3 - 6 } & $\mathbf{( m )}$ & $\begin{array}{c}\boldsymbol{\delta} \mathbf{x e} \\
\mathbf{( m m})\end{array}$ & $\begin{array}{c}\boldsymbol{\delta} \mathbf{x i} \\
\mathbf{( m m})\end{array}$ & $\begin{array}{c}\boldsymbol{\delta} \mathbf{x e} \\
\mathbf{( m m})\end{array}$ & $\begin{array}{c}\boldsymbol{\delta} \mathbf{x i} \\
\mathbf{( m m})\end{array}$ \\
\hline 4 & 4,2 & 7,517 & 27,563 & 14,653 & 53,726 \\
3 & 4,2 & 5,724 & 20,989 & 11,120 & 40,774 \\
2 & 4,2 & 3,637 & 13,337 & 7,093 & 26,007 \\
1 & 4,5 & 1,624 & 5,953 & 3,265 & 11,970 \\
Base & 0 & - & - & - & - \\
\hline
\end{tabular}


Tabel 9. Simpangan Lateral Lantai Arah X

\begin{tabular}{|c|c|c|c|c|c|}
\hline \multirow[b]{2}{*}{ Lt } & \multirow[b]{2}{*}{$\begin{array}{c}\mathbf{H}_{\mathbf{x}} \\
(\mathrm{m})\end{array}$} & \multicolumn{2}{|c|}{ Jakarta } & \multicolumn{2}{|c|}{ B. Lampung } \\
\hline & & $\begin{array}{c}\delta x e \\
(\mathrm{~mm})\end{array}$ & $\begin{array}{c}\delta x i \\
(\mathrm{~mm})\end{array}$ & $\begin{array}{c}\delta x e \\
(\mathrm{~mm})\end{array}$ & $\begin{array}{c}\delta x i \\
(\mathrm{~mm})\end{array}$ \\
\hline 4 & 4,2 & 21,726 & 79,663 & 22,667 & 83,112 \\
\hline 3 & 4,2 & 16,482 & 60,432 & 17,244 & 63,227 \\
\hline 2 & 4,2 & 10,569 & 38,751 & 11,140 & 40,848 \\
\hline 1 & 4,5 & 4,960 & 18,185 & 5,369 & 19,685 \\
\hline Base & 0 & - & - & - & - \\
\hline
\end{tabular}

Tabel 9. Simpangan Lateral Lantai Arah X (Lanjutan)

\begin{tabular}{cccc}
\hline \multirow{4}{*}{ Lt } & \multirow{2}{*}{$\begin{array}{c}\mathbf{H}_{\mathbf{x}} \\
\end{array}$} & $\begin{array}{c}\boldsymbol{\delta} \mathbf{c} \text { Palu } \\
(\mathbf{m m})\end{array}$ & $\begin{array}{c}\boldsymbol{\delta} \mathbf{x i} \\
(\mathbf{m m})\end{array}$ \\
\hline 4 & 4,2 & 23,745 & 87,065 \\
3 & 4,2 & 18,068 & 66,249 \\
2 & 4,2 & 11,707 & 42,924 \\
1 & 4,5 & 5,691 & 20,865 \\
Base & 0 & - & - \\
\hline
\end{tabular}

Tabel 10. Simpangan Lateral Lantai Arah Y

\begin{tabular}{|c|c|c|c|c|c|}
\hline \multirow[b]{2}{*}{ Lt } & \multirow[b]{2}{*}{$\begin{array}{l}\mathbf{H}_{y} \\
(\mathrm{~m})\end{array}$} & \multicolumn{2}{|c|}{ Pontianak } & \multicolumn{2}{|c|}{ Palembang } \\
\hline & & $\begin{array}{c}\text { סye } \\
(\mathrm{mm})\end{array}$ & $\begin{array}{c}\delta y i \\
(\mathrm{~mm})\end{array}$ & $\begin{array}{c}\text { Sye } \\
(\mathrm{mm})\end{array}$ & $\begin{array}{c}\delta y i \\
(\mathrm{~mm})\end{array}$ \\
\hline 4 & 4,2 & 7,439 & 27,275 & 14,516 & 53,226 \\
\hline 3 & 4,2 & 5,680 & 20,828 & 11,007 & 40,358 \\
\hline 2 & 4,2 & 3,622 & 13,280 & 7,009 & 25,700 \\
\hline 1 & 4,5 & 1,626 & 5,963 & 3,243 & 11,891 \\
\hline Base & 0 & - & - & - & - \\
\hline
\end{tabular}

Tabel 10. Simpangan Lateral Lantai Arah Y (Lanjutan)

\begin{tabular}{|c|c|c|c|c|c|}
\hline \multirow[b]{2}{*}{ Lt } & \multirow[b]{2}{*}{$\begin{array}{l}\mathbf{H}_{\mathrm{y}} \\
(\mathrm{m})\end{array}$} & \multicolumn{2}{|c|}{ Jakarta } & \multicolumn{2}{|c|}{ B. Lampung } \\
\hline & & $\begin{array}{c}\text { Sye } \\
(\mathrm{mm})\end{array}$ & $\begin{array}{c}\delta y i \\
(\mathrm{~mm})\end{array}$ & $\begin{array}{c}\text { Sye } \\
(\mathrm{mm})\end{array}$ & $\begin{array}{c}\delta y i \\
(\mathrm{~mm})\end{array}$ \\
\hline 4 & 4,2 & 21,598 & 79,192 & 22,586 & 82,814 \\
\hline 3 & 4,2 & 16,344 & 59,926 & 17,114 & 62,750 \\
\hline 2 & 4,2 & 10,441 & 38,283 & 10,990 & 40,298 \\
\hline 1 & 4,5 & 4,925 & 18,059 & 5,326 & 19,530 \\
\hline Base & 0 & - & - & - & - \\
\hline
\end{tabular}

Tabel 10. Simpangan Lateral Lantai Arah Y (Lanjutan)

\begin{tabular}{cccc}
\hline & \multirow{2}{*}{$\mathbf{H}$} & \multicolumn{2}{c}{ Palu } \\
\cline { 3 - 4 } & $\mathbf{( m )}$ & $\begin{array}{c}\boldsymbol{\delta} \mathbf{e} \\
\mathbf{( m m})\end{array}$ & $\begin{array}{c}\boldsymbol{\delta} \mathbf{y i} \\
\mathbf{( m m})\end{array}$ \\
\hline 4 & 4,2 & 23,690 & 86,863 \\
3 & 4,2 & 17,940 & 65,781 \\
2 & 4,2 & 11,543 & 42,325 \\
1 & 4,5 & 5,643 & 20,691 \\
Base & 0 & - & - \\
\hline
\end{tabular}

Tabel 11. Simpangan Antar Lantai Arah X

\begin{tabular}{ccccccc}
\hline \multirow{2}{*}{ Lt } & \multirow{H}{*}{$\mathbf{H x}$} & \multirow{2}{*}{$\boldsymbol{\Delta}_{\mathbf{X i j i n}}$} & \multicolumn{2}{c}{ Pontianak } & \multicolumn{2}{c}{ Palembang } \\
\cline { 4 - 7 } & $\mathbf{n n y y y y}$ & & $\boldsymbol{\Delta}_{\mathbf{x i}}$ & Ket & $\boldsymbol{\Delta}_{\mathbf{X i}}$ & Ket \\
\hline 4 & 4,2 & 63 & 6,57 & OK & 12,95 & OK \\
3 & 4,2 & 63 & 7,65 & OK & 14,77 & OK \\
2 & 4,2 & 63 & 7,38 & OK & 14,04 & OK \\
1 & 4,5 & 67,5 & 5,95 & OK & 11,97 & OK \\
Base & 0 & - & - & - & - & - \\
\hline
\end{tabular}

Tabel 11. Simpangan Antar Lantai Arah X (Lanjutan)

\begin{tabular}{ccccccc}
\hline \multirow{2}{*}{ Lt } & \multirow{H}{*}{$\mathbf{H}$} & \multirow{2}{*}{$\boldsymbol{\Delta}_{\mathbf{X i j i n}}$} & \multicolumn{2}{c}{ Jakarta } & \multicolumn{2}{c}{ B. Lampung } \\
\cline { 4 - 7 } & $\mathbf{m})$ & & $\boldsymbol{\Delta}_{\mathbf{x i}}$ & $\mathbf{K e t}$ & $\boldsymbol{\Delta}_{\mathbf{X i}}$ & Ket \\
\hline 4 & 4,2 & 63 & 19,23 & OK & 19,88 & OK \\
3 & 4,2 & 63 & 21,68 & OK & 22,38 & OK \\
2 & 4,2 & 63 & 20,57 & OK & 21,16 & OK \\
1 & 4,5 & 67,5 & 18,18 & OK & 19,68 & OK \\
Base & 0 & - & - & - & - & -
\end{tabular}

Tabel 11. Simpangan Antar Lantai Arah $X$ (Lanjutan)

\begin{tabular}{ccccc}
\hline \multirow{2}{*}{$\mathbf{L t}$} & \multirow{2}{*}{$\mathbf{H x}(\mathbf{m})$} & \multirow{2}{*}{$\mathbf{x}$ ijin } & \multicolumn{2}{c}{ Palu } \\
\cline { 4 - 5 } & & & $\boldsymbol{\Delta} \mathbf{x i}$ & Ket \\
\hline 4 & 4,2 & 63 & 20,81 & OK \\
3 & 4,2 & 63 & 23,32 & OK \\
2 & 4,2 & 63 & 22,06 & OK \\
1 & 4,5 & 67,5 & 20,86 & OK \\
Base & 0 & - & - & - \\
\hline
\end{tabular}

Tabel 12. Simpangan Antar Lantai Arah Y

\begin{tabular}{lllllll}
\hline \multirow{2}{*}{ Lt } & $\begin{array}{l}\text { Hy } \\
\text { (m) }\end{array}$ & \multirow{2}{*}{$\boldsymbol{\Delta}_{\text {Yijin }}$} & \multicolumn{2}{c}{ Pontianak } & \multicolumn{2}{c}{ Palembang } \\
\cline { 4 - 7 } & & $\boldsymbol{\Delta}_{\mathbf{Y i}}$ & Ket & $\boldsymbol{\Delta}_{\mathbf{Y i}}$ & Ket \\
\hline 4 & 4,2 & 63 & 6,44 & OK & 12,87 & OK \\
3 & 4,2 & 63 & 7,55 & OK & 14,66 & OK \\
2 & 4,2 & 63 & 7,32 & OK & 13,81 & OK \\
1 & 4,5 & 67,5 & 5,96 & OK & 11,89 & OK \\
Base & 0 & - & - & - & - & - \\
\hline
\end{tabular}

Tabel 12. Simpangan Antar Lantai Arah $Y$ (Lanjutan)

\begin{tabular}{lllllll}
\hline \multirow{2}{*}{ Lt } & \multirow{2}{*}{$\begin{array}{l}\text { Hy } \\
\text { (m) }\end{array}$} & \multirow{2}{*}{$\boldsymbol{y}_{\text {Yijin }}$} & \multicolumn{2}{c}{ Jakarta } & \multicolumn{3}{c}{ B. Lampung } \\
\cline { 4 - 7 } & 4,2 & 63 & 19,27 & OK & 20,06 & OK \\
\hline 4 & 4,2 & Ket & $\boldsymbol{\Delta}_{\mathbf{Y i}}$ & Ket \\
3 & 4,2 & 63 & 21,64 & OK & 22,45 & OK \\
2 & 4,2 & 63 & 20,22 & OK & 20,77 & OK \\
1 & 4,5 & 67,5 & 18,06 & OK & 19,53 & OK \\
Base & 0 & - & - & - & - & - \\
\hline
\end{tabular}

Tabel 12. Simpangan Antar Lantai Arah Y (Lanjutan)

\begin{tabular}{lllll}
\hline \multirow{2}{*}{ Lt } & $\begin{array}{l}\text { Hy } \\
\text { (m) }\end{array}$ & \multirow{2}{*}{$\boldsymbol{\Delta}_{\text {Yijin }}$} & Palu & \\
\cline { 4 - 5 } & 4,2 & 63 & 21,08 & OK \\
\hline 4 & 4,2 & 63 & 23,46 & OK \\
3 & 4,2 & 63 & 21,63 & OK \\
2 & 4,5 & 67,5 & 20,69 & OK \\
1 & 0 & - & - & - \\
Base & 0 & & & \\
\hline
\end{tabular}

Dari perhitungan simpangan antar lantai yang disajikan dalam Tabel 11 dan 12, didapat bahwa simpangan antar lantai terbesar terdapat pada wilayah Palu dan yang terkecil terdapat pada wilayah Pontianak. Hal ini dikarenakan simpangan lateral pada wilayah Palu memiliki nilai yang besar dan hal tersebut juga diakibatkan karena gaya gempa yang besar. Simpangan antar lantai yang terbesar terdapat pada lantai 4 disetiap wilayahnya, hal ini dikarenakan distribusi gaya yang berpengaruh terhadap tinggi gedung. Perbedaan simpangan pada masing-masing wilayah disajikan pada Gambar 4, 5, 6 dan 7. 


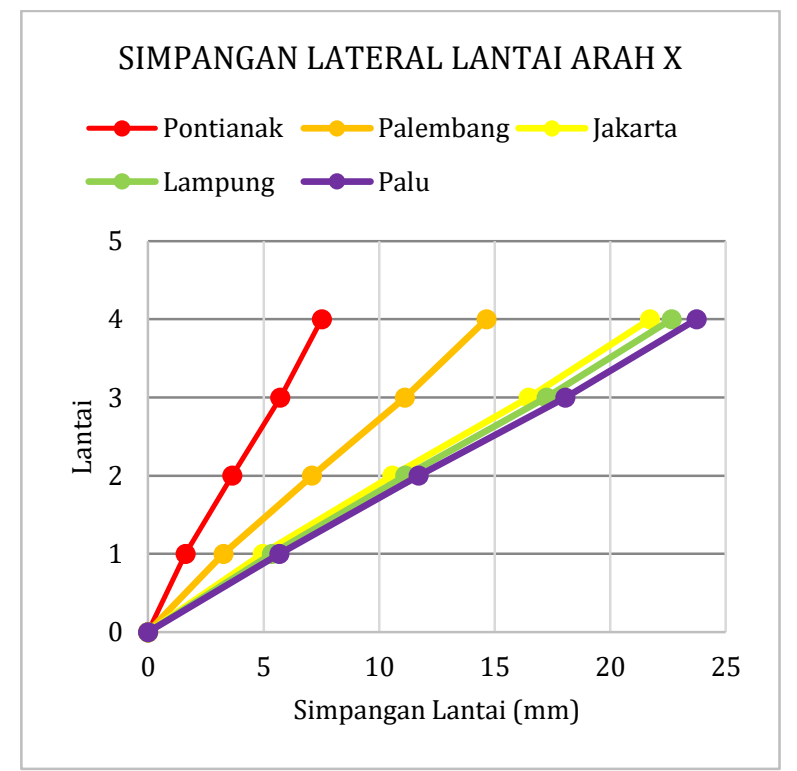

Gambar 4. Simpangan Lateral Lantai Arah X

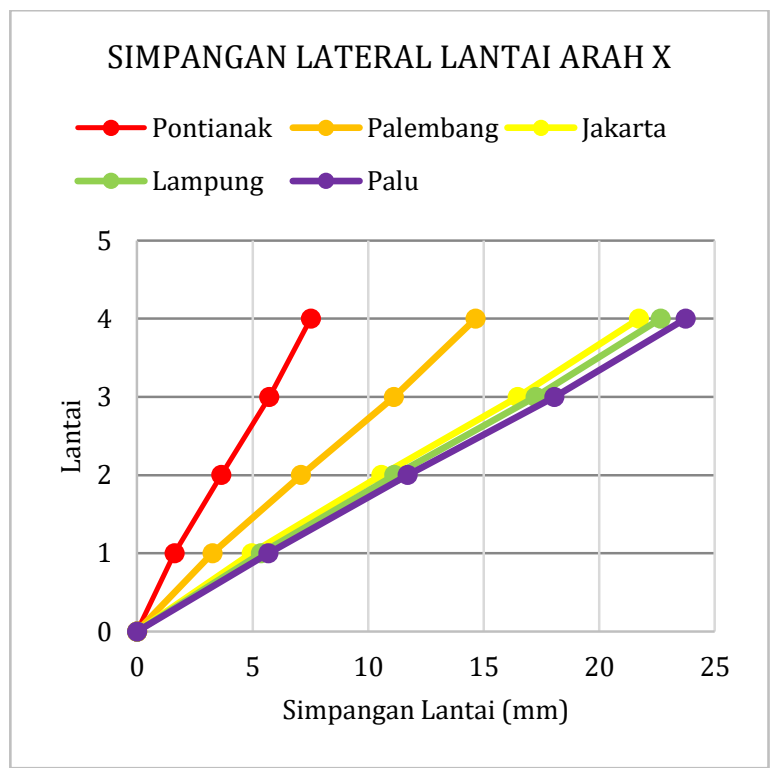

Gambar 5. Simpangan Lateral Lantai Arah Y

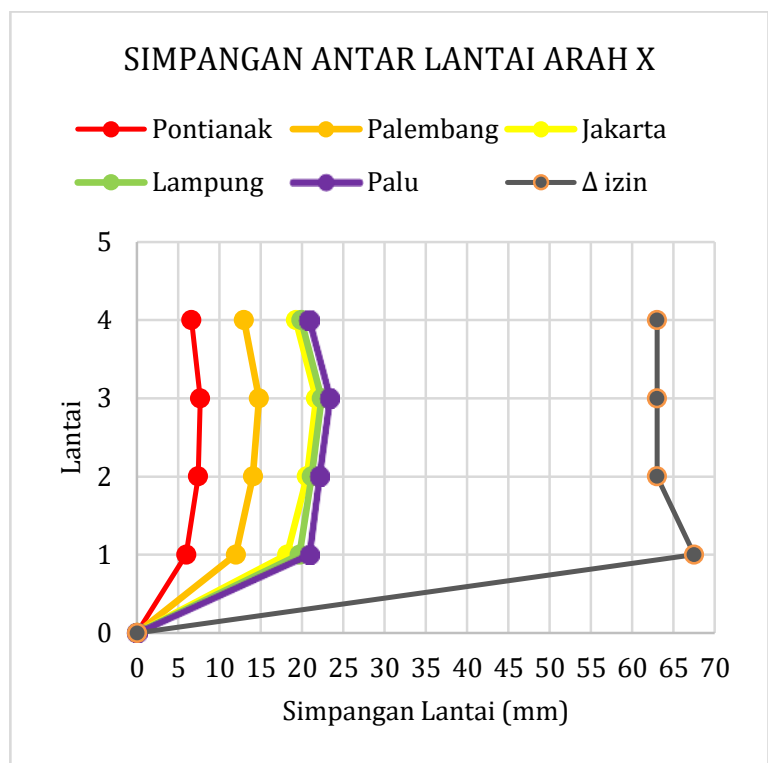

Gambar 6. Simpangan Antar Lantai Arah X

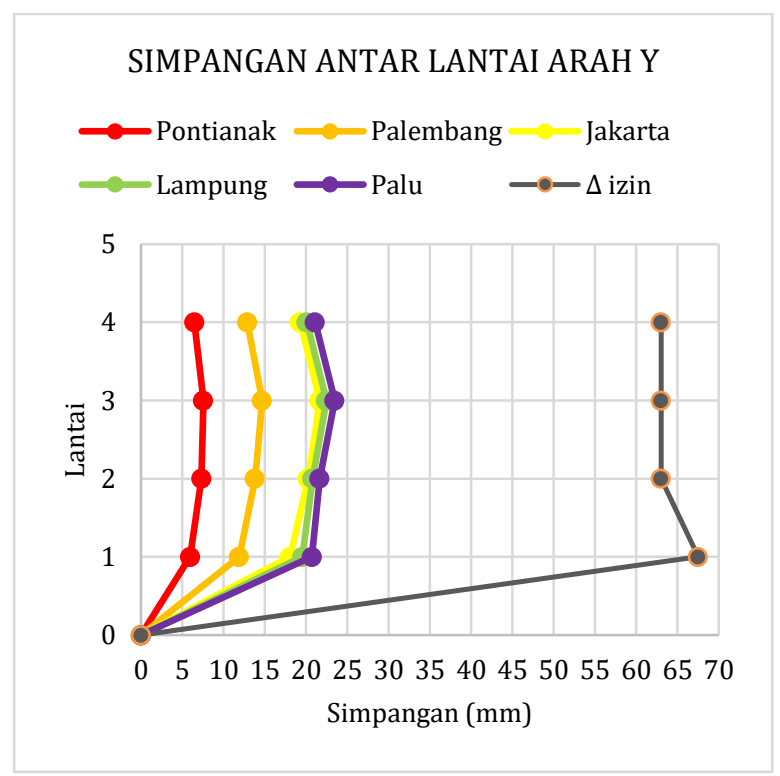

Gambar 7. Simpangan Antar Lantai Arah y

\section{Hasil Analisis Kinerja Struktur}

Untuk menentukan level kinerja struktur pada setiap wilayah, maka dilakukan perhitungan target perpindahan pada wilayah tersebut. Besaran target perpindahan dapat dilihat pada Tabel 13.

Tabel 13. Target Perpindahan pada Masing-Masing Wilayah

\begin{tabular}{ccccc}
\hline \multirow{2}{*}{ Koef } & \multicolumn{2}{c}{ Pontianak } & \multicolumn{2}{c}{ Palembang } \\
\cline { 2 - 5 } & $\mathbf{X}$ & $\mathbf{Y}$ & $\mathbf{X}$ & $\mathbf{Y}$ \\
\hline $\mathrm{T}_{\mathrm{e}}$ & 0,583 & 0,583 & 0,583 & 0,580 \\
$\mathrm{~T}_{\mathrm{s}}$ & 0,5 & 0,5 & 1,1 & 1,1 \\
$\mathrm{C}_{0}$ & 1,4 & 1,4 & 1,4 & 1,4 \\
$\mathrm{C}_{1}$ & 1,0 & 1,0 & 1,1 & 0,8 \\
$\mathrm{C}_{2}$ & 1,0 & 1,0 & 1,0 & 1,1 \\
$\mathrm{C}_{3}$ & 1,0 & 1,0 & 1,0 & 1,0 \\
$\mathrm{~S}_{\mathrm{a}}$ & 0,306 & 0,306 & 0,689 & 0,689 \\
$\mathrm{~g}\left(\mathrm{~m} / \mathrm{s}^{2}\right)$ & 9,81 & 9,81 & 9,81 & 9,81 \\
$\delta_{\mathrm{T}}(\mathrm{m})$ & 0,037 & 0,037 & 0,084 & 0,066 \\
\hline
\end{tabular}

Tabel 13. Target Perpindahan pada Masing-Masing Wilayah (Lanjutan)

\begin{tabular}{ccccc}
\hline \multirow{2}{*}{ Koef } & \multicolumn{2}{c}{ Jakarta } & \multicolumn{2}{c}{ B. Lampung } \\
\cline { 2 - 5 } & $\mathbf{X}$ & $\mathbf{Y}$ & $\mathbf{X}$ & $\mathbf{Y}$ \\
\hline $\mathrm{T}_{\mathrm{e}}$ & 0,574 & 0,572 & 0,559 & 0,557 \\
$\mathrm{~T}_{\mathrm{s}}$ & 0,9 & 0,9 & 0,9 & 0,9 \\
$\mathrm{C}_{0}$ & 1,4 & 1,4 & 1,4 & 1,4 \\
$\mathrm{C}_{1}$ & 1,0 & 1,0 & 1,0 & 1,0 \\
$\mathrm{C}_{2}$ & 1,0 & 1,0 & 1,0 & 1,0 \\
$\mathrm{C}_{3}$ & 1,0 & 1,0 & 1,0 & 1,0 \\
$\mathrm{~S}_{\mathrm{a}}$ & 0,908 & 0,908 & 0,919 & 0,919 \\
$\mathrm{~g}\left(\mathrm{~m} / \mathrm{s}^{2}\right)$ & 9,81 & 9,81 & 9,81 & 9,81 \\
$\delta_{\mathrm{T}}(\mathrm{m})$ & 0,105 & 0,104 & 0,101 & 0,100 \\
\hline
\end{tabular}

Tabel 13. Target Perpindahan pada Masing-Masing Wilayah (Lanjutan)

\begin{tabular}{ccc}
\hline \multirow{2}{*}{ Koef } & \multicolumn{2}{c}{ Palu } \\
\cline { 2 - 3 } & $\mathbf{X}$ & $\mathbf{Y}$ \\
\hline $\mathrm{T}_{\mathrm{e}}$ & 0,556 & 0,554 \\
$\mathrm{~T}_{\mathrm{s}}$ & 0,9 & 0,9
\end{tabular}




\begin{tabular}{ccc}
\hline \multirow{2}{*}{ Koef } & \multicolumn{2}{c}{ Palu } \\
\cline { 2 - 3 } & $\mathbf{X}$ & $\mathbf{Y}$ \\
\hline $\mathrm{C}_{0}$ & 1,4 & 1,4 \\
$\mathrm{C}_{1}$ & 1,1 & 1,1 \\
$\mathrm{C}_{2}$ & 1,0 & 1,0 \\
$\mathrm{C}_{3}$ & 1,0 & 1,0 \\
$\mathrm{~S}_{\mathrm{a}}$ & 1,350 & 1,350 \\
$\mathrm{~g}\left(\mathrm{~m} / \mathrm{s}^{2}\right)$ & 9,81 & 9,81 \\
$\delta_{\mathrm{T}}(\mathrm{m})$ & 0,151 & 0,149 \\
\hline
\end{tabular}

Dari hasil Tabel 13, perbedaan dari hasil target perpindahan disebabkan karena adanya perbedaan pada beban lateral yang bekerja pada struktur masing-masing wilayah. Setelah ditentukan target perpindahan, kemudian hasil analisis pushover akan dievaluasi untuk menentukan level kinerja struktur yang ditentukan berdasarkan penyebaran sendi plastis. Kurva kapasitas pada arah X dan arah Y dari hasil analisis pushover pada setiap wilayah dapat dilihat pada Gambar 8 dan 9.

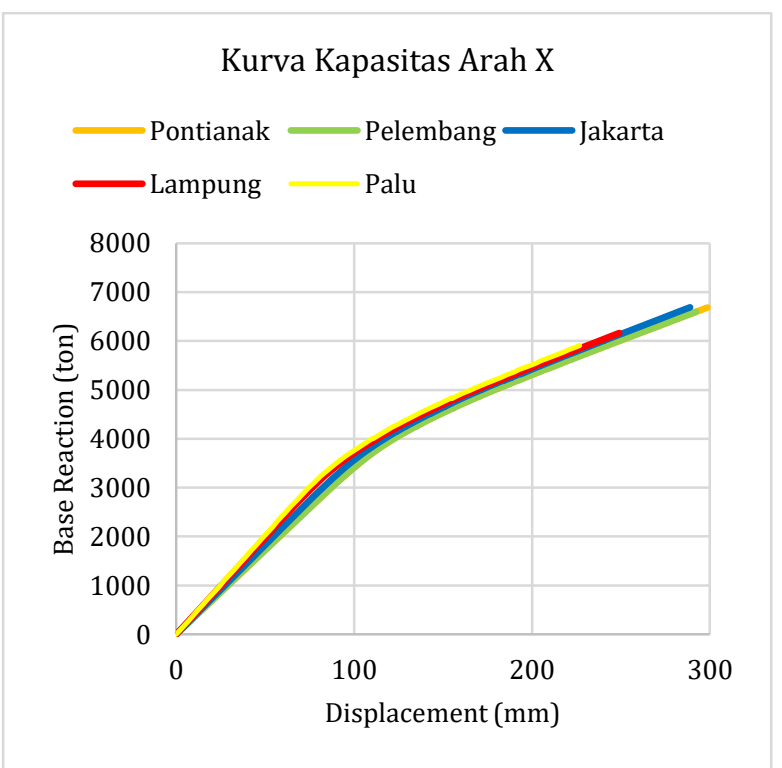

Gambar 8. Kurva Kapasitas Arah X

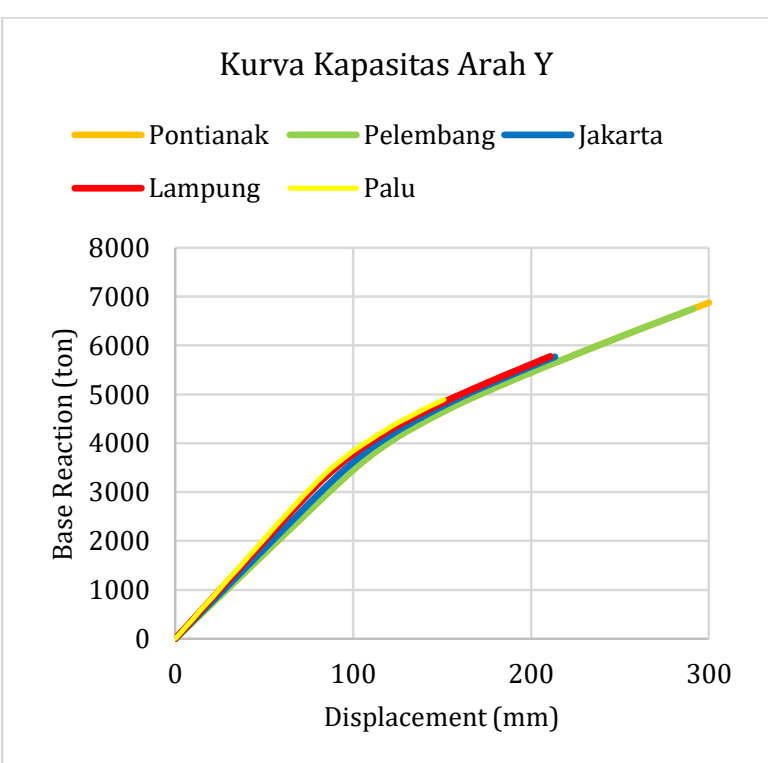

Gambar 9. Kurva Kapasitas Arah Y
Dari penyebaran sendi plastis, didapatkan tiga kondisi penyebaran sendi palstis yaitu pada kondisi target perpindahan tercapai, pada kondisi terjadinya leleh pertama, dan pada kondisi mencapai kondisi ultimit. Untuk menentukan level kinerja dari struktur, kondisi penyebaran sendi plastis yang dibutuhkan adalah pada saat mencapai kondisi tercapainya target perpindahan. Dengan tercapainya target perpindahan, maka dapat ditentukan titik kinerja yang didapat pada masingmasing wilayah. Rekapitulasi penyebaran sendi plastis pada kondisi tercapainya titik kinerja dapat dilihat pada Tabel 14.

Tabel 14. Penyebaran Sendi Plastis pada Kondisi Titik Kinerja (Performance Point)

\begin{tabular}{lccc}
\hline \multirow{2}{*}{ Wilayah } & \multicolumn{3}{c}{ Arah X } \\
\cline { 2 - 4 } & Step & $\begin{array}{c}\text { Base Force } \\
\text { (ton) }\end{array}$ & $\begin{array}{c}\text { Disp } \\
\text { (mm) }\end{array}$ \\
\hline Pontianak & 13 & 1343,38 & 39.00 \\
Palembang & 28 & 2899,54 & 84,20 \\
Jakarta & 33 & 3740,27 & 106,36 \\
Bandar Lampung & 32 & 3826,21 & 104,95 \\
Palu & 52 & 4839,58 & 155,15 \\
\hline
\end{tabular}

Tabel 14. Penyebaran Sendi Plastis pada Kondisi Titik Kinerja (Performance Point) (Lanjutan)

\begin{tabular}{lccc}
\hline \multirow{1}{*}{ Wilayah } & \multicolumn{3}{c}{ Arah Y } \\
\cline { 2 - 4 } & Step & $\begin{array}{c}\text { Base Shear } \\
\text { (ton) }\end{array}$ & $\begin{array}{c}\text { Disp } \\
\text { (mm) }\end{array}$ \\
\hline Pontianak & 13 & 1356,26 & 39,00 \\
Palembang & 23 & 2399,07 & 69,00 \\
Jakarta & 33 & 3795,30 & 106,23 \\
Bandar Lampung & 31 & 3792,16 & 100,50 \\
Palu & 44 & 4895,47 & 151,02 \\
\hline
\end{tabular}

Dari rekapitulasi penyebaran sendi plastis pada Tabel 14, maka dapat ditentukan level kinerjanya yang disajikan pada Tabel 15.

Tabel 15. Level Kinerja Struktur

\begin{tabular}{lcc}
\hline \multirow{2}{*}{ Wilayah } & \multicolumn{2}{c}{ Level Kinerja } \\
\cline { 2 - 3 } & Arah $\mathbf{X}$ & Arah $\mathbf{~}$ \\
\hline Pontianak & IO & IO \\
Palembang & IO & IO \\
Jakarta & IO & IO \\
Lampung & IO & IO \\
Palu & IO & B \\
\hline
\end{tabular}

Dari Tabel 15, dapat dilihat bahwa wilayah Palu berada pada level kinerja B dan IO dimana level kinerja tersebut pada arah $\mathrm{Y}$ tidak terjadi kerusakan baik struktural maupun nonstruktural sedangkan pada arah $\mathrm{X}$, struktur mengalami kerusakan non struktural, namun struktur tersebut masih memiliki kekuatan yang sama sebelum struktur diberikan gaya. Hal ini dipengarui oleh dimensi elemen struktur pada wilayah Palu lebih besar dibandingkan dengan wilayah lainnya, sehingga kekakuan bangunan pada wilayah Palu lebih tinggi dibandingkan dengan wilayah lainnya. Semakin kaku suatu bangunan maka semakin kuat bangunan tersebut dapat menahan beban yang 
diberikan. Oleh karena itu pada wilayah Palu tidak mengalami kerusakan elemen struktural maupun non-struktural dan dihasilkan level kinerja B.

\section{KESIMPULAN}

Hasil analisis linear menunjukkan bahwa gaya geser terbesar dimiliki oleh gedung di wilayah Palu sebesar 764,97 ton, sedangkan gaya geser terkecil dimiliki oleh gedung di wilayah Pontianak sebesar 185,16 ton. Hal ini disebabkan karena gaya gempa yang terjadi pada wilayah Palu, lebih besar dibandingkan dengan wilayah lainnya, sehingga nilai koefisien kegempaan yang didapat lebih besar dan memengaruhi nilai gaya geser dasar seismik. Besaran gaya geser dasar pada struktur ini akan memengaruhi nilai dari simpangan lateral dan simpangan antar lantai, sehingga nilai simpangan lateral dan simpangan antar lantai pada struktur, berbanding lurus dengan nilai gaya geser dasar. Hasil analisis kinerja struktur berdasarkan analisis pushover pada masing-masing wilayah memiliki level kinerja B dan didominasi IO. Dimana Struktur yang berada pada level kinerja B terjadi di wilayah Palu arah Y, sedangkan untuk struktur yang lainnya berada pada level kinerja IO. Level kinerja yang didapatkan relatif sama (IO), hal ini dikarenakan struktur memiliki kekakuan yang cukup tinggi sehingga struktur mampu menahan gaya yang bekerja sampai batas level kinerja IO. Bila kondisi ini dihubungkan dengan dimensi elemen struktur, maka dapat disimpulkan bahwa dibutuhkan dimensi elemen struktur yang lebih besar di wilayah gempa tinggi untuk mencapai kondisi elemen struktur yang aman agar analisis dapat dilanjutkan pada analisis pushover, sehingga kekakuan dan level kinerja struktur menjadi meningkat.

\section{REFERENSI}

[1] A. S. Elnashai and L. Di Sarno, Fundamentals of Earthquake Engineering. John Wiley and Sons, 2008.

[2] A. J. Pierre and I. Hidayat, "Seismic performance of reinforced concrete structures with pushover analysis," IOP Conf. Ser. Earth Environ. Sci., vol. 426, no. 1, p. 012045, Feb. 2020.

[3] F. P. Hsiao, Y. Oktavianus, and Y. C. Ou, "A pushover seismic analysis method for asymmetric and tall buildings," J. Chinese Inst. Eng. Trans. Chinese Inst. Eng. A, vol. 38, no. 8, 2015.

[4] R. Cornelis, W. Bunganaen, and B. H. U. Tay, "Analisis Perbandingan Gaya Geser Tingkat, Gaya Geser Tingkat dan Simpangan Antar Tingkat Akibat Beban Gempa Berdasarkan Peraturan Gempa SNI 1726-2002 dan SNI 1726-2012," Tek. Sipil, vol. III, no. 2, pp. 205216, 2014.

[5] Badan Standardisasi Nasional, "SNI 1726:2019 Tata Cara Perencanaan Ketahanan Gempa
Untuk Struktur Bangunan Gedung dan Nongedung." 2019.

[6] Badan Standardisasi Nasional, "SNI 1727:2020 Beban Desain Minimum dan Kriteria Terkait Untuk Bangunan Gedung dan Struktur Lain." 2020.

[7] N. H. Crista, T. N. Widorini, and L. N. Anggraini, "Perbandingan Tulangan Lentur pada Gedung Fakultas Psikologi Universitas Semarang dengan Membandingkan Peraturan SNI Gempa 2012 dengan SNI Gempa 2019," J. Pengemb. Rekayasa dan Teknol., vol. 16, no. 2, pp. 143-162, 2020.

[8] B. Nasution and A. Purqon, "Uji Respon Struktur Bangunan Bertingkat Terhadap Gempa Bumi Menggunakan Metode Elemen Hingga," in Prosiding SNIPS 2016, 2016.

[9] I. Samsya, "Evaluasi Aplikasi Penggunaan Base Isolation pada Gedung Grand Keisha Menggunakan Analisa Pushover," Institut Teknologi Sepuluh November, Surabaya, 2017.

[10] R. N. Pujianto, “Analisis Gempa Non-Linier Statik Pushover Dengan Metode Fema 440 Untuk Evaluasi Kinerja Struktur Bangunan Gedung," in Prosiding Seminar Nasional: Keandalan Infrastruktur Pekerjaan Umum Perumahan Rakyat Bagi Kemajuan Bangsa, 2019, pp. 129-142.

[11] FEMA, "Improvement of Nonlinear Static Seismic Analysis Procedures," FEMA 440, Federal Emergency Management Agency, Washington DC, vol. 440, no. June. p. 392, 2005.

[12] Tavio and U. Wijaya, Desain Rekayasa Gempa Berbasis Kinerja (Performance Based Design), 2nd ed. Andi, 2018.

[13] D. Purnamasari, "Analisis Kinerja Struktur Beton Bertulang dengan Variasi Konfigurasi Dinding Geser Menggunakan Pushover Analysis," Universitas Sriwijaya, 2019.

[14] W. A, R. Suryanita, and Z. Djauhari, "Prediksi Respons Struktur Gedung Berdasarkan Respons Spektrum Gempa Indonesia Menggunakan Metode Jaringan Saraf Tiruan," J. Sainstek STT Pekanbaru, vol. 4, no. 1, pp. 1-15, 2016.

[15] B. Junita, "Respon Struktur Bangunan Tinggi dengan Variasi Penempatan Outrigger Terhadap Beban Lateral (Studi Kasus: Bangunan Tower A ST. Moritz Panakukang)," Universitas Negeri Jakarta, 2018.

\section{NOMENKLATUR}

B1 Jenis pertama elemen balok

B2 Jenis kedua elemen balok

BA Balok anak

$\mathrm{C}_{\mathrm{u}} \quad$ Koefisien untuk batasan atas pada periode yang dihitung

$\mathrm{C}_{\mathrm{t}}$ dan x Parameter periode pendekatan

$\mathrm{C}_{\mathrm{s}} \quad$ Koefisien desain seismik 
$\mathrm{C}_{0} \quad$ Faktor modifikasi untuk perpindahan spektral menjadi perpindahan atap/puncak (lantai teratas yang tidak dihuni). Umumnya menggunakan faktor partisipasi ragam pertama atau berdasarkan Tabel 3-2 dari FEMA 356.

$\mathrm{C}_{1} \quad$ Faktor modifikasi untuk menghubungkan perpindahan inelastik maksimum dengan perpindahan yang dihitung dari respons elastik linier.

$\mathrm{C}_{2} \quad$ Faktor modifikasi yang mewakili efek dari bentuk histeretis pada perpindahan maksimum.

$\mathrm{C}_{3} \quad$ Koefisien untuk memperhitungkan pembesaran lateral akibat efek P-Delta. Jika gedung pada kondisi pasca leleh kekakuannya positif (kurva meningkat) maka $\mathrm{C}_{3}=1$.

$\mathrm{C}_{\mathrm{d}} \quad$ Faktor pembesaran simpangan lateral

DL Beban mati (dead load)

$\mathrm{h}_{\mathrm{n}} \quad$ Tinggi total bangunan

I $\quad$ Faktor keutamaan gempa

LL Beban hidup (live load)

$\mathrm{R} \quad$ Koefisien modifikasi respons

RX0 Beban gempa arah X tanpa eksentrisitas

RX1 Beban gempa arah X dengan eksentrisitas

RY0 Beban gempa arah Y tanpa eksentrisitas

RY1 Beban gempa arah Y dengan eksentrisitas

$\mathrm{S}_{\mathrm{s}} \quad$ Periode pendek

$\mathrm{S}_{1} \quad$ Periode 1 detik

$\mathrm{S}_{\mathrm{a}} \quad$ Akselerasi respon spektrum yang berhubungan dengan waktu getar alami efektif pada arah yang ditinjau

$\mathrm{S}_{\mathrm{DS}} \quad$ Parameter percepatan respons spektral pada periode pendek

$\mathrm{S}_{\mathrm{D} 1} \quad$ Parameter percepatan respons spektral pada periode 1 detik

$\mathrm{T}_{\mathrm{a}} \quad$ Periode fundamental pendekatan

$\mathrm{T}_{\mathrm{e}} \quad$ Waktu getar efektif

$\mathrm{T}_{\mathrm{x}} \quad$ Time period arah $\mathrm{X}$

$\mathrm{T}_{0}$ dan $\mathrm{T}_{\mathrm{s}}$ Ambang batas penentuan periode fundamental

V Gaya geser dasar seismik

W Berat struktur

$\Omega_{0} \quad$ Faktor kuat lebih

$\delta_{\mathrm{e}} \quad$ Simpangan pusat massa di tingkat-x

$\delta_{\mathrm{i}} \quad$ Simpangan pada lokasi yang disyaratkan

$\Delta_{\text {izin }} \quad$ Simpangan antar lantai izin

$\Delta_{\mathrm{I}} \quad$ Simpangan antar lantai

$\Delta_{\mathrm{x}} \quad$ Target perpindahan 